\title{
PURIFICATION AND CHARACTERIZATION OF A NEW XYLANASE FROM HUMICOLA GRISEA VAR. THERMOIDEA
}

\author{
Severino de Albuquerque Lucena-Neto; Edivaldo Ximenes Ferreira-Filho* \\ Laboratório de Enzimologia, Departamento de Biologia Celular, Universidade de Brasília, Brasília, DF, Brasil.
}

Submitted: November 05, 2002; Returned to authors: July 25, 2003; Approved: February 10, 2004.

\begin{abstract}
The thermophilic fungus Humicola grisea var. thermoidea secretes extracellular xylanase when grown on solid and in liquid media containing wheat bran and banana plant residue as substrates, respectively. At $55^{\circ} \mathrm{C}$, xylanase from the culture filtrate of $H$. grisea var. thermoidea grown on banana stalk retained $50 \%$ of its activity after $28 \mathrm{~h}$ of incubation. A xylanase (X2) was isolated from solid state cultures with wheat bran as the carbon source. It was purified to apparent homogeneity by ultrafiltration followed by ion-exchange and hydrophobic interaction chromatography on DEAE-Sepharose and Phenyl-Sepharose resins, respectively. The enzyme had an apparent molecular weight of $29 \mathrm{kDa}$, as determined by SDS-PAGE. The purified enzyme was most active at $\mathrm{pH}$ and temperature ranges of 4.5-6.5 and $55-60^{\circ} \mathrm{C}$, respectively. In addition, $\mathrm{X} 2$ showed thermostability at $60^{\circ} \mathrm{C}$ with a half-life of approx. $5.5 \mathrm{~h}$. The apparent $\mathrm{Km}$ values, using soluble and insoluble arabinoxylans as substrates, were 10.87 and $11.20 \mathrm{mg} / \mathrm{ml}$, respectively.
\end{abstract}

Key words: Humicola grisea, xylan, xylanase

\section{INTRODUCTION}

Xylanases have potential applications in the food, chemical, pharmaceutical and paper industries $(8,17)$. These enzymes are produced by several fungal species, including Humicola grisea var. thermoidea. The thermophilic fungus $H$. grisea var. thermoidea has attracted attention as a rich source of xylanolytic enzymes $(1,13,20)$. Earlier studies have demonstrated that $H$. grisea var. thermoidea produces xylanases with different molecular masses. Some properties of these purified enzymes have been published $(13,22)$. Solid-state cultivation on wheat bran as a substrate is an efficient procedure for xylanase production $(17,23)$. Some of the advantages of the use of solidstate cultivation over liquid medium are described such as lower costs and the production of enzymes with higher specific activities (11). The banana plant (Musa cavendishii) produces a residual component named fruit stalk with holocellulose and lignin corresponding to $33 \%$ and $8.67 \%$ of the dry weight of this component, respectively (11). An earlier study reported the ability of $H$. grisea var. thermoidea to grow and produce xylanase activity in a medium containing banana stalk (11). In this study, we report the inductive effect of banana stalk on the xylanase activity of $\mathrm{H}$. grisea var. thermoidea when grown in a liquidstate medium. The purification and some properties of a new xylanase (X2) from solid-state cultures of the fungus on wheat bran as a carbon source are also described.

\section{MATERIALS AND METHODS}

\section{Growth conditions}

For the production of xylanase in a solid-state medium containing wheat bran as the carbon source, $H$. grisea var. thermoidea was cultured at $42^{\circ} \mathrm{C}$ for 7 days (20). After the growth procedure, the protein content of the solid-state culture flasks was extracted with $500 \mathrm{ml}$ of $25 \mathrm{mM}$ sodium phosphate buffer, pH 7.0 and placed on a rotary shaker $(100 \mathrm{rpm})$ at room temperature for $3 \mathrm{~h}$. The resulting crude extract was centrifuged for $30 \mathrm{~min}$ at $9,600 \mathrm{~g}$ and $4^{\circ} \mathrm{C}$, filtered and stored at $5^{\circ} \mathrm{C}$ for

*Corresponding author. Mailing address: Laboratório de Enzimologia, Departamento de Biologia Celular, Universidade de Brasília. 70910-900, Brasília, DF, Brasil. Tel.: (+5561) 3072152. Fax: (+5561) 2734608. E-mail: eximenes@unb.br 
subsequent use as source of xylanase. $H$. grisea var. thermoidea was also grown at $40^{\circ} \mathrm{C}$ for $72 \mathrm{~h}$ with rotary shaking $(100 \mathrm{rpm})$ in 1-liter Erlenmeyer flasks containing $300 \mathrm{ml}$ of medium. Liquid cultures were inoculated with $10^{7}$ spores $\mathrm{ml}^{-1}$ from a 7 -day old culture. The composition of the medium (w/v) was as follows: $0.5 \%$ banana stalk, $0.7 \% \mathrm{KH}_{2} \mathrm{PO}_{4}, 0.2 \% \mathrm{~K}_{2} \mathrm{HPO}_{4}, 0.05 \%$ $\mathrm{MgSO}_{4} .7 \mathrm{H}_{2} \mathrm{O}, 0.1 \%\left(\mathrm{NH}_{4}\right)_{2} \mathrm{SO}_{4}$, and $0.06 \%$ yeast extract. The content of each flask was filtered through filter paper and hereafter called crude extract. For experiments on induction of xylanase activity, aliquots were harvested every 6 h during 16 days, and used to measure xylanase activity.

\section{Assays}

Xylanase activity was routinely determined by mixing 100 $\mathrm{ml}$ of enzyme solution with $200 \mathrm{ml}$ of oat spelt xylan $(1 \%, \mathrm{w} / \mathrm{v})$ in $100 \mathrm{mM}$ sodium acetate buffer, $\mathrm{pH} 5.0$ at $50^{\circ} \mathrm{C}$ for $30 \mathrm{~min}$. The release of reducing sugar was measured using the dinitrosalicylic reagent method (12). Xylose was used as the standard. Xylanase activity was expressed as $\mu \mathrm{mol}$ of reducing sugar formed per milliliter and minute of enzyme solution, i.e., as IU $\mathrm{ml}^{-1}$. Cellulase assay was carried out as described above using carboxymethylcellulose (CMC) as substrate. Protein concentration was quantified by the Bradford method (3) using bovine serum albumin as the standard. For the kinetic experiments, soluble and insoluble samples from oat spelt xylan were used as substrates in a concentration range of $1.5-25 \mathrm{mg} / \mathrm{ml}$ and $10-50$ $\mathrm{mg} / \mathrm{ml}$, respectively. The substrates were prepared as described by Filho et al. (7). $\mathrm{K}_{\mathrm{m}}$ and $\mathrm{V}_{\max }$ values were estimated from the Michaelis-Menten equation with a non-linear regression data analysis program (10). The determination of optimum temperature of $\mathrm{X} 2$ was carried out in the temperature range of 30 to $80^{\circ} \mathrm{C}$. To determine the optimum $\mathrm{pH}$ of $\mathrm{X} 2$ activity at $50^{\circ} \mathrm{C}$, the range was from 3.0 to 8.0. The McIlvaine type buffer systems were adjusted with the same ionic strength with $\mathrm{KCl}$ (5). Temperature stability was determined by pre-incubating an enzyme sample at $55^{\circ} \mathrm{C}$ or $60^{\circ} \mathrm{C}$. At various time periods, aliquots were withdrawn and the residual activity was measured under standard conditions. All activity values were repeated at least three times.

\section{Enzyme Purification}

All purification steps were carried out at $4{ }^{\circ} \mathrm{C}$ unless otherwise specified. The crude extract was concentrated and dialyzed (against $25 \mathrm{mM}$ sodium phosphate buffer, $\mathrm{pH}$ 7.0) by ultrafiltration using an Amicon system with a $10 \mathrm{kDa}$ cut-off point membrane (PM 10). The retentate was applied to a DEAESepharose column $(2.5 \times 9.5 \mathrm{~cm})$ pre-equilibrated with $50 \mathrm{mM}$ sodium acetate buffer, $\mathrm{pH}$ 5.5. The column was washed with the same buffer and eluted with a linear gradient of $\mathrm{NaCl}(0-1 \mathrm{M})$. Fractions of $5.2 \mathrm{ml}$ were collected at a flow rate of $90 \mathrm{ml} / \mathrm{h}$. The fractions containing the highest xylanase activity were pooled from successive runs and submitted to hydrophobic interaction chromatography in a Phenyl-Sepharose column equilibrated with the above buffer at a flow rate of $120 \mathrm{ml} / \mathrm{h}$. The residual protein was eluted with an ammonium sulphate descending gradient from 1 to $0 \mathrm{M}$. Fractions of $4.0 \mathrm{ml}$, corresponding to xylanase activity were pooled, concentrated by ultrafiltration and stored for later use at $4^{\circ} \mathrm{C}$.

\section{Electrophoresis}

Sodium dodecyl sulfate-polyacrylamide electrophoresis (SDS-PAGE) was carried out as described by Laemmli (9) using $12 \%$ gels. After electrophoresis, the protein bands were silver stained by the method of Blum et al. (2). Low molecular weight standards from Sigma (USA) were used as size markers. A SDSPAGE gel (12\%) containing $1 \%$ oat spelt xylan was submitted to zymogram analysis (14). It was stained for xylanase activity in a Congo red solution $(0.1 \%)$ for $30 \mathrm{~min}$ at room temperature and washed with $1 \mathrm{M} \mathrm{NaCl}$ to remove excess dye and fixed with $0.5 \%$ acetic acid.

\section{Chemicals}

Oat spelt xylan was purchased from Sigma Chemical Co., St. Louis, MO 63178, USA. Wheat bran was obtained from a local source. Banana stalk was kindly provided by Francides Gomes da Silva Jr. (University of São Paulo, Brasil). All other chemical were analytical grade reagents.

\section{RESULTS AND DISCUSSION}

The induction profile after growth of $H$. grisea var. thermoidea on fruit stalk as substrate showed that the time lag for induction of $\beta$-xylanase was about $18 \mathrm{~h}$ and thereafter the activity increased steadily and reached its highest value at $264 \mathrm{~h}$ of cultivation (results not shown). The growth profile was accompanied by several peaks of xylanase activity. Xylanase activity isolated from crude extract of $H$. grisea var. thermoidea grown on $0.5 \%$ banana stalk was most active over a temperature range of 55 to $60^{\circ} \mathrm{C}$. It dropped to $50 \%$ of its original activity after $28 \mathrm{~h}$ incubation at $55^{\circ} \mathrm{C}$. The influence of banana stalk on xylanase thermostability can not be discarded. Components of lignocellulosic substrates (coarse corn cobs) were found to improve the thermostability of crude xylanases from Thermomyces lanuginosus (21).

Procedure for purification of a new $\beta$-xylanase, $\mathrm{X} 2$, from $H$. grisea var. thermoidea, grown on wheat bran as substrate, is summarized in Table 1 . The crude extract was concentrated by ultrafiltration and purified by a simple two step procedure on ion-exchange and hydrophobic interaction chromatographies. A major xylanase activity was detected in the concentrated crude extract (retentate), while a small amount of enzyme activity was found in the filtrate (permeate). The ability of xylanases to penetrate an ultrafiltration membrane has been reported before $(18,19,23)$. It is suggested to be due to xylanase compact structure 
and/or non-uniformity of membrane pore size $(15,18)$. The retentate elution in DEAE-Sepharose chromatography resulted in the separation of two peaks of xylanase activity. X2 was eluted in the pre-gradient fractions, while the second xylanase activity was adsorbed to the ion exchange resin (Fig. 1). Further purification of X2 on Phenyl-Sepharose column showed three peaks of protein containing xylanase activity eluted after application of an ammonium sulphate descending gradient (Fig. 2). The fractions representing the third protein peak were pooled. After the Phenyl-Sepharose step, the enzyme was purified to apparent homogeneity as determined in a SDS$12 \%$ polyacrylamide gel (Fig. 3 ). The recovery of X2 was very low $(6.40 \%)$, probably due to the presence of other xylandegrading activities determined during the purification steps. We observed the presence of at least five xylanase activity peaks. The multiplicity of forms is commonly described for $\beta$ xylanases from fungi and bacteria as the result of differential mRNA processing and posttranslational modifications $(7,19)$.

Table 1. Summary of the purification of xylanase (X2) from $H$. grisea var. thermoidea.

\begin{tabular}{cccccc}
\hline Step & $\begin{array}{c}\text { Total } \\
\text { protein } \\
(\mathrm{mg})\end{array}$ & $\begin{array}{c}\text { Total } \\
\text { activity } \\
(\mathrm{U})\end{array}$ & $\begin{array}{c}\text { Specific } \\
\text { activity } \\
\left(\mathrm{U} \mathrm{mg}^{-1}\right)\end{array}$ & $\begin{array}{c}\text { Yeld } \\
(\%)\end{array}$ & $\begin{array}{c}\text { Purification } \\
\text { (-fold) }\end{array}$ \\
\hline $\begin{array}{c}\text { Culture filtrate } \\
\text { DEAE }\end{array}$ & 204.74 & 318.63 & 1.56 & 100 & 1 \\
$\begin{array}{c}\text { Sepharose } \\
\text { Phenyl }\end{array}$ & 20.92 & 85.00 & 4.07 & 26.66 & 2.61 \\
Sepharose & 4.58 & 32.60 & 10.23 & 6.40 & 4.55 \\
\hline
\end{tabular}

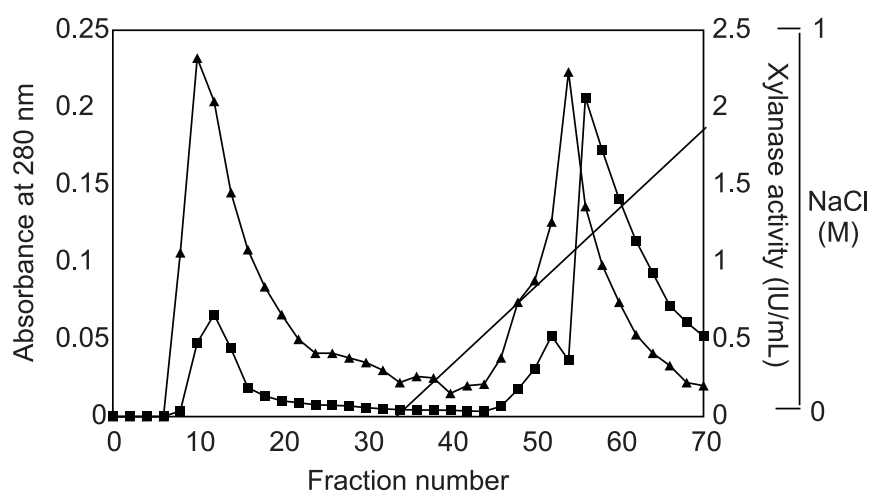

Figure 1. Fractionation on DEAE-Sepharose of Humicola grisea var. thermoidea crude extract., xylanase activity.
Since these enzymes act synergistically for the complete hydrolysis of xylan, the yield and fold values were probably underestimated. Furthermore, a small level of xylanase was present in the ultrafiltrate. Ultrafiltration procedure is reported to reduce xylanase recovery yields (15). Low purification yields for xylanase activities are often reported in the literature $(7,15,18,22,23)$.

The enzyme migrated as a single $29 \mathrm{kDa}$ band on SDS-PAGE (Fig. 3). The molecular weight found for $\mathrm{X} 2$ was within the range

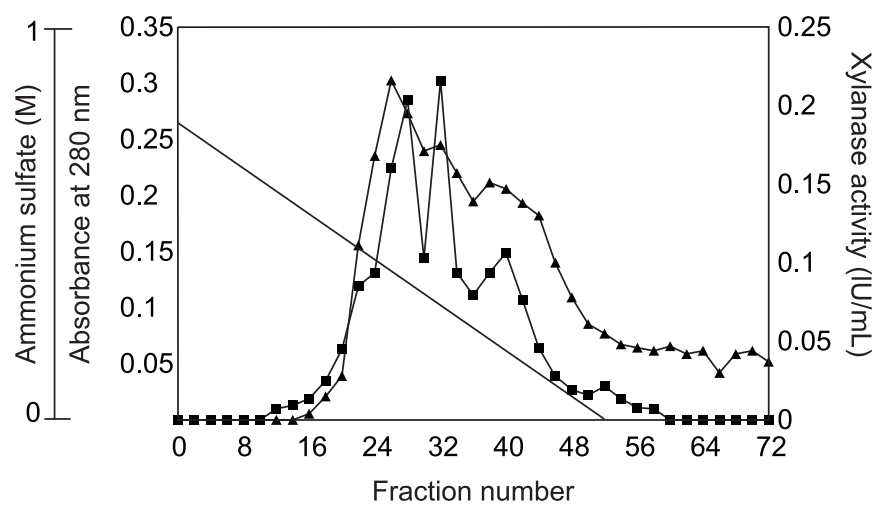

Figure 2. Hydrophobic interaction chromatography of $\beta$ xylanase activity on Phenyl-Sepharose, - $\boldsymbol{\square}$ - absorbance at 280 $\mathrm{nm} ;-\boldsymbol{\Delta}$ - xylanase activity.

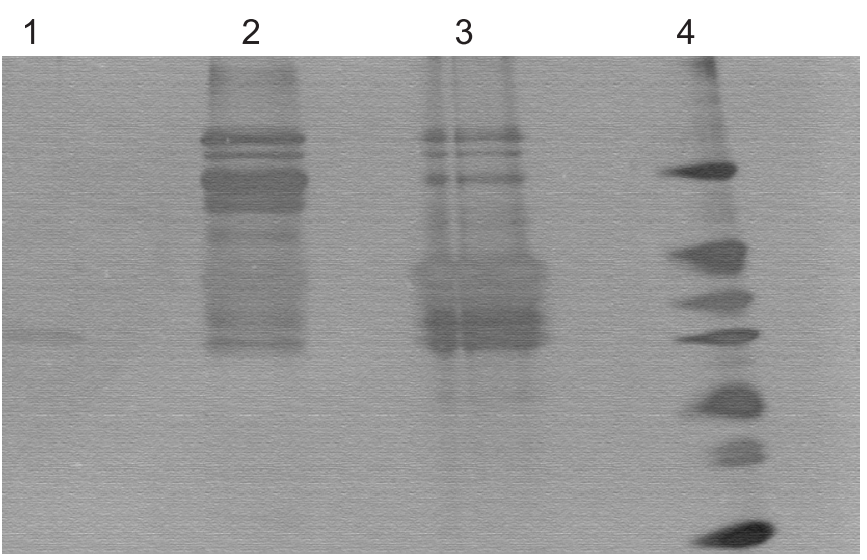

Figure 3. SDS-PAGE of X2 from Humicola grisea var. thermoidea. Lane 1, X2; lane 2, first xylanase peak from Phenyl Sepharose chromatography; lane 3, second xylanase peak from Phenyl Sepharose chromatography; lane 4; molecular weight standards (from the top): bovine serum albumin $(66 \mathrm{kDa})$, ovalbumin $(45$ $\mathrm{kDa})$, glyceraldehyde-3-phosphate dehydrogenase (36 kDa), carbonic anhydrase $(29 \mathrm{kDa})$, trypsinogen $(24 \mathrm{kDa})$, trypsin inhibitor (20 kDa), lactalbumin (14.2 kDa), aprotinin (6.5 kDa). 
detected for xylanases belonging to the family G/11 (16). Smaller xylanases are able to penetrate further the fiber wall structure and modify more efficiently pulp properties (16). The molecular weight of X2 differed from the ones purified from crude extract samples of the same fungus strain, which were 13, 23, 25.5 and $95 \mathrm{kDa}(13,22)$. The zymogram analysis was performed by renaturing X2 after SDS-PAGE. It showed enzyme activity that was visualized by staining with Congo red corresponded to the protein band (result not shown). The xylanase zymogram of the second protein peak from DEAE Sepharose chromatography revealed two xylanase-active bands.

Some of the properties of X2 are shown in Table 2. The purified enzyme gave the highest activity at a temperature range of $55-60^{\circ} \mathrm{C}$. This result was higher than the values reported for some xylanases from Acrophialophora nainiana, Trichoderma harzianum and Penicillium capsulatum $(7,18,23)$. It was lesser than those of xylanase forms 1 and 2 from the same fungus (13) and similar to Xyl1 and Xyl2 from Humicola insolens (6). It is noteworthy that X2 was subjected to 30-min assay, while xylanase forms 1 and 2 had an incubation time of only $15 \mathrm{~min}$. On the other hand, $\mathrm{X} 2$ showed better stability at $60^{\circ} \mathrm{C}$. After 5.5 $\mathrm{h}$ incubation at $60^{\circ} \mathrm{C}$, the enzyme retained $50 \%$ of its original activity, while xylanase form 2 had a half life of only 20 min at the same temperature. $\mathrm{Xyl} 2$ from $H$. insolens lost its activity completely after $45 \mathrm{~min}$ at $60^{\circ} \mathrm{C}(6)$. The degree of thermostability of X2 was also higher than those found for specific and non specific xylanases from $P$. capsulatum (7) and XynIII of $A$. nainiana (4). In contrast to the xylanase forms 1 and 2, Xyl1 and $\mathrm{Xyl} 2$, X2 was optimal at a broader $\mathrm{pH}$ range of 4.5-6.5. Furthermore, X2 only showed a residual activity against CMC. The xylanases from family G/11 are reported to be cellulasefree (16).

The kinetic parameters of X2 were investigated using soluble and insoluble forms of oat spelt xylan as substrate (Table 2). The enzyme showed higher affinity for the branched xylan (soluble form). The hydrolysis of soluble oat spelt xylan was more effective than when the enzyme was incubated with the insoluble xylan, suggesting that the presence of a particular type of substituent (arabinofuranosyl group) in the vicinity would be a requirement for the action of X2 (19). In this case,

Table 2. Some properties of purified X2 from Humicola grisea var. thermoidea.

$\begin{array}{lr}\text { Molecular weight (SDS-PAGE) } & 29 \mathrm{kDa} \\ \text { Highest } \mathrm{pH} & 4.5-6.5 \\ \text { Highest temperature } & 55-65^{\circ} \mathrm{C} \\ \text { Thermostability at } 60^{\circ} \mathrm{C} \text { (half-life) } & 5.5 \mathrm{~h} \\ \mathrm{Km} \text { (soluble xylan) } & 10.87 \mathrm{mg} / \mathrm{ml} \\ \mathrm{Km} \text { (insoluble xylan) } & 11.20 \mathrm{mg} / \mathrm{ml}\end{array}$

the substituent is required for the proper orientation of the substrate in the catalytic site (18). However, the hypothesis that the substituents are probably located in regions of the substrate distant from the unsubstituted portions can not be discarded (18). Xyl 1 and Xyl 2 from $H$. insolens require a sequence of at least three unsubstituted xylose residues for their active binding (23).

In conclusion, for the bioconversion of lignocellulose residues, it is desirable to have a microorganism capable of producing a range of enzyme activities that interact synergistically (10). In our case, $H$. grisea var. thermoidea produced a xylanase activity when grown in the presence of banana stalk or wheat bran as the carbon source. Since xylanases with useful $\mathrm{pH}$ optima and high temperature stabilities are of commercial importance, the wide $\mathrm{pH}$ profile and good thermostability of X2 make it a valuable tool for application in the process of prebleaching cellulose pulps. Based on its small molecular weight, X2 is suggested to belong to family $\mathrm{G} / 11$.

\section{ACKNOWLEDGEMENTS}

This work was funded by PADCT III/CNPq. S.A.L.N. and E.X.F.F. acknowledge receipt of a post-graduate maintenance scholarship and research fellowship from CAPES and CNPq, respectively.

\section{RESUMO}

\section{Produção, purificação e caracterização de uma nova Xilanase de Humicola grisea var. Thermoidea}

O fungo termofílico Humicola grisea var. secreta xilanase extracelular quando cultivado em meios sólidos e líquidos contendo farelo de trigo e engaço de bananeira como substratos, respectivamente. À temperatura de $55^{\circ} \mathrm{C}$, xilanase do filtrado de meio de cultura de $H$. grise $a$ var. thermoidea cultivado em engaço de bananeira reteve $50 \%$ de sua atividade após 28 de incubação. Uma xilanase (X2) foi isolada de culturas de estado sólido contendo farelo de trigo como fonte de carbono. X2 foi purificada por ultrafiltração, seguido por cromatografias de interação hidrofóbica e troca iônica em resinas de Phenyl-Sepharose e DEAE-Sepharose, respectivamente. A enzima apresentou peso molecular de $29 \mathrm{kDa}$, como determinado por SDS-PAGE. Aenzima purificada foi mais ativa em intervalos de $\mathrm{pH}$ e temperatura de 4,5-6,5 and $55-60^{\circ} \mathrm{C}$, respectivamente. Além disso, X2 mostrou termoestabilidade a $60^{\circ} \mathrm{C}$ com meia vida de aproximadamente 5,5 h. Os valores de $\mathrm{Km}$ aparente, utilizando arabinoxilanas solúveis e insolúveis, foram 10,87 and $11,20 \mathrm{mg} / \mathrm{ml}$, respectivamente.

Palavras-chave: Humicola grisea, xilana, xilanase 


\section{REFERENCES}

1. Almeida, E.M.; Polizeli, M.L.T.M.; Terenzi, H.F.; Jorge, J.A. Purification and biochemical characterization of $\beta$-xylosidase from Humicola grisea var. thermoidea. FEMS Microbiol. Lett., 130: 171176, 1995.

2. Blum, H.; Beier, H.; Gross, B. Improved silver staining of plant proteins, RNA and DNA in polyacrylamide gels. Electrophoresis, 8: 93-99, 1987.

3. Bradford, M.M. A rapid and sensitive method for the quantitation of microgram quantities of protein utilizing the principle of protein dye binding. Anal. Biochem., 72: 248-25, 1976.

4. Cardoso, O.A.V.; Filho, E.X.F. Purification and characterization of a novel cellulase-free xylanase from Acrophialophora nainiana. FEMS Microbiol. Lett., 223: 309-314, 2003.

5. Dawson, R.M.C.; Elliot, D.C.; Elliott, W.H.; Jones, K.M. pH, buffers and physiological media. In: Dawson, R.M.C.; Elliott, D.C.; Elliott, W.H.; Jones, K.M. (eds). Data for Biochemical Research. Research University Press, Oxford, 1969, p.501-502.

6. Düsterhöft, E.M.; Linssen, V.A.J.; Voragen, A.G.J.; Beldman, G. Purification, characterization, and properties of two xylanases from Humicola insolens. Enzyme Microb. Technol., 20: 437-44, 1997.

7. Filho, E.X.F.; Puls, J.; Coughlan, M.P. Biochemical characteristics of two endo-b-1,4-D-xylanases produced by Penicillium capsulatum. J. Ind. Microbiol., 11: 171-180, 1993.

8. Kulkarni, N.; Shendye, A.; Rao, M. Molecular and biotechnological aspects of xylanases. FEMS Microbiol. Rev., 23: 411-456, 1999.

9. Laemmli, U.K. Cleavage of structural proteins during the assembly of the head of bacteriophage T4. Nature, 227: 680-685, 1970.

10. Leatherbarrow, R.J. Enzifitter: a non-linear regression data analysis program for the IBM PC. Biosoft, London, 1987, p.1-91.

11. Medeiros, R.G.; Soffner, M.L.A.; Thomé, J.A.; Cacais, A.O.G.; Estelles, R.S.; Salles, B.C.; Ferreira, H.M.; Lucena Neto, S.A.; Silva Jr., F.G.; Filho, E.X.F. The production of hemicellulases by aerobic fungi on medium containing residues of banana plant as substrate. Biotechnol. Progress, 16: 522-524, 2000.

12. Miller, G.L. Use of dinitrosalicylic acid reagent for the determination of reducing sugar. Anal. Chem., 31: 426-428, 1959.
13. Monti, R.; Terenzi, H.F.; Jorge, J.A. Purification and characterization of an extracellular xylanase from the thermophilic fungus Humicola grisea var. thermoidea. Can. J. Microbiol., 37: 675-681, 1991.

14. Ratanakhanokchai, K.; Kyu, K.L.; Tanticharoen, M. Purification and properties of a xylan-binding endoxylanase from alkaliphilic Bacillus sp. strain K-1. Appl. Environ. Microbiol., 65: 694-697, 1999.

15. Sá-Pereira, P.; Paveia, H.; Costa-Ferreira; Aires-Barros, R. A new look at xylanases. Mol. Biotechnol., 24: 257-281, 2003.

16. Salles, B.C.; Cunha, R.B.; Fontes, W.; Sousa, M.V.; Filho, E.X.F. Purification and characterization of a new xylanase from Acrophialophora nainiana. J. Biotechnol., 81: 199-204, 2000.

17. Silveira, F.Q.P.; Ximenes, F.A.; Cacais, A.O.G.; Milagres, A.M.F.; Medeiros, C.L.; Filho, E.X.F. Hydrolysis of xylans by enzyme systems from solid state cultures of Trichoderma harzianum strains. Brazilian J. Med. Biol. Res., 32: 947-952, 1999a.

18. Silva, C.H.C.; Puls, J.; Sousa, M.V.; Filho, E.X.F. Purification and characterization of a low molecular weight xylanase from solidstate cultures of Aspergillus fumigatus fresenius. Brazilian J. Microbiol., 30: 114-119, 1999.

19. Silva, C.H.C.; Fonsêca, A.S.; Lucena Neto, S.A.; Ximenes, E.A.; Puls, J.; Filho, E.X.F. Evaluation of hydrolysis products of xylandegrading enzymes from Humicola grisea var. thermoidea and Aspergillus fumigatus Fresenius. World J. Microbiol. Biotechnol., 16: 81-83, 2000.

20. Silveira, F.Q.P.; Sousa, M.V.; Ricart, C.A.O.; Milagres, A.M.F.; Medeiros, C.L.; Filho, E.X.F. A new xylanase from a Trichoderma harzianum strain. J. Ind. Microbiol. Biotechnol, 23: 682-685, 1999 b.

21. Singh, S.; Pillay, B.; Prior, B.A. Thermal stability of $\beta$-xylanases produced by different Thermomyces lanuginosus strains. Enzyme Microb. Technol., 26: 502-508, 2000.

22. Thakur, I.S.; Rana, B.K.; Johri, B.N. Multiplicity of xylanase in Humicola grisea var. thermoidea. In: Visser, J.; Beldman, G.; Someren, M.A.K. (eds.) Xylans and xylanases. Elsevier Applied Science, Amsterdam, 1992, p.511-514.

23. Ximenes, F.A.; Sousa, M.V.; Puls, J.; Silva Jr., F.G.; Filho, E.X.F. Purification and characterization of a low molecular weight xylanase produced by Acrophialophora nainiana. Curr. Microbiol., 38: 18$21,1999$. 